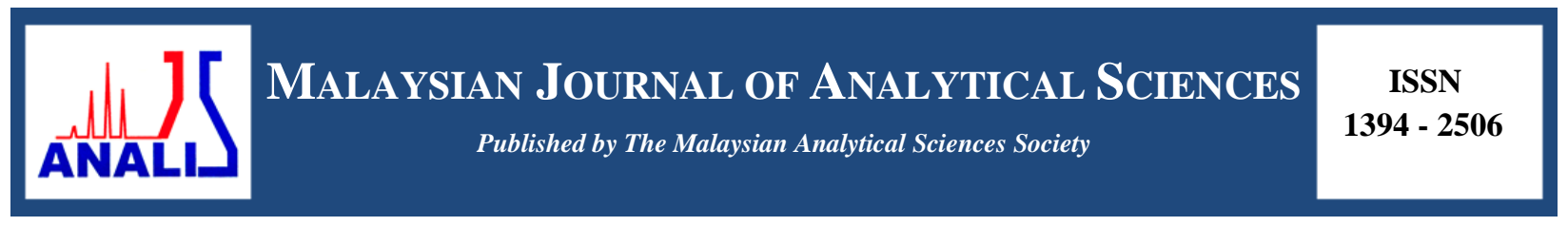

\title{
EFFECT OF USING PITAYA PEEL AS DYE-SENSITIZER AND DYE MOLECULES IN ELECTROLYTE FOR PHOTOELECTROCHEMICAL REACTION
}

\author{
(Kesan Penggunaan Kulit Buah Naga Sebagai Pemeka-Pewarna dan Molekul Pewarna di dalam \\ Elektrolit bagi Tindak Balas Fotoelektrokimia)
}

\author{
Siti Nur Hidayah Jaafar ${ }^{1}$, Lorna Jeffery Minggu ${ }^{1}$, Khuzaimah Ariffin ${ }^{1}$, Mohammad B. Kasssim ${ }^{1,2}$, \\ Wan Ramli Wan Daud ${ }^{1,3}$ \\ ${ }^{1}$ Fuel Cell Institute \\ ${ }^{2}$ School of Chemical Sciences and Food Technology, Faculty of Science and Technology \\ ${ }^{3}$ Department of Chemical and Process Engineering, Faculty of Engineering and Built Environment, \\ Universiti Kebangsaan Malaysia, 43600 UKM Bangi, Selangor, Malaysia \\ *Corresponding author: lorna_jm@ukm.edu.my
}

Received: 5 February 2016; Accepted: 22 April 2016

\begin{abstract}
Natural dye sensitizer in photoelectrochemical shows a great potential in improving the efficiency of metal oxide semiconductor especially Titanium dioxide $\left(\mathrm{TiO}_{2}\right)$ due to its prominent in absorbing visible light and also low cost. In this work, the effect of using pitaya peel as natural dye sensitizes to $\mathrm{TiO}_{2}$ has been studied through characterizations analysis and PEC test. The bare $\mathrm{TiO}_{2}$ thin films were fabricated on Fluorine-doped tin oxide (FTO) glass substrate by doctor blade method meanwhile dyesensitized $\mathrm{TiO}_{2}$ thin films prepared by immersion of $\mathrm{TiO}_{2}$ in the dye extracts. The fabricated thin films were characterized with Scanning Electron Microscopy (SEM), X-ray difractometer (XRD), UV-Vis spectrophotometer and photoelectrochemical analysis. The surface of $\mathrm{TiO}_{2}$ was porous and uniform meanwhile dye particles could not been observed due to very small size. The energy band gap of dye-sensitized $\mathrm{TiO}_{2}$ from the UV-Vis spectrum is $2.1 \mathrm{eV}$ which is smaller than bare $\mathrm{TiO}_{2}(3.7 \mathrm{eV})$. Meanwhile, photoactivities of dye-sensitized $\mathrm{TiO}_{2}$ has the highest compared to bare $\mathrm{TiO}_{2}$ photoelectrodes which is $127 \mu \mathrm{A} / \mathrm{cm}^{2}$ in $6.25 \% \mathrm{v} / \mathrm{v}$ of pitaya dye in the electrolyte.
\end{abstract}

Keywords: titanium dioxide, dye-sensitizers, betalains, photoelectrochemical cell, water splitting

\begin{abstract}
Abstrak
Pemeka-pewarna semulajadi di dalam fotoelektromia (PEC) menunjukkan potensi yang bagus untuk meningkatkan keupayaan semikonduktor logam oksida terutamanya titanium dioksida $\left(\mathrm{TiO}_{2}\right)$ disebabkan kemampuannya untum menyerap cahaya nampak dan kos yang rendah. Di dalam penyelidikan ini, kesan menggunakan kulit buah naga sebagai pemeka-pewarna semulajadi terhadap $\mathrm{TiO}_{2}$ telah dikaji melalui pencirian dan analisis fotoelektrokimia. Filem nipis $\mathrm{TiO}_{2}$ asli telah dihasilkan melalui kaedah Doctor blade di atas kepingan kaca bersalut FTO (Stanum oksida terdop fluorin) manakala filem nipis $\mathrm{TiO}_{2}$ dengan pewarnapemeka telah dihasilkan dengan merendam $\mathrm{TiO}_{2}$ ke dalam larutan ekstrak pewarna. Filem nipis yang telah terbentuk telah melalui beberapa analisis pencirian iaitu, Mikroskopi Elektron Imbasan (SEM), Difraktometer Pembelauan Sinar-X (XRD), Spektrofotometer Ultralembayung dan Cahaya Nampak (UV-Vis) dan juga ujian fotoelektrokimia. Permukaan $\mathrm{TiO}_{2}$ adalah berliang dan seragam manakala zarah pewarna tidak dapat dilihat disebabkan saiznya yang terlalu kecil. Jurang tenaga filem nipis $\mathrm{TiO}_{2}$ dengan pewarna-pemeka adalah lebih rendah iaitu $2.1 \mathrm{eV}$ jika dibandingkan dengan $\mathrm{TiO}_{2}$ asli $(3.7 \mathrm{eV})$. Manakala, fotoaktiviti bagi fotoelektrod $\mathrm{TiO}_{2}$ dengan pewarna-pemeka adalah lebih tinggi daripada $\mathrm{TiO}_{2}$ asli dengan $127 \mu \mathrm{A} / \mathrm{cm}^{2}$ di dalam kepekatan $6.25 \% \mathrm{v} / \mathrm{v}$ pewarna di dalam elektrolit.
\end{abstract}


Kata kunci: titanium dioksida, pemeka-pewarna, betalain, sel fotoelektrokimia, pembelahan air

\section{Introduction}

The hydrogen gas production by using solar energy is deliberated as one of the most significant sustainable and clean energy technologies [1]. Photoelectrochemical (PEC) water splitting is the most promising method in generating hydrogen gas. Metal oxide semiconductor such as $\mathrm{TiO}_{2}, \mathrm{SnO}_{2}$, and $\mathrm{WO}_{3}$ is widely studied as having a great potential as photoelectrodes in PEC system [2]. Nonetheless, $\mathrm{TiO}_{2}$ semiconductor is more favorable due to its good stability in thermal and chemical properties, inexpensive and non-toxic [3]. However, $\mathrm{TiO}_{2}$ is characterized by its wide band gap of $3.2 \mathrm{eV}$ (anatase phase) and required Ultra-Violet (UV) irradiation which only absorb small fraction $(<10 \%)$ of the sunlight energy [3,4]. An improvement of $\mathrm{TiO}_{2}$ semiconductor can be achieved by using dye sensitizer plays as a main role in absorbing light energy in production of hydrogen [4]. Dye sensitizer has been widely studied caused by its great potential as sunlight harvester and improved PEC efficiency by increased light absorption in solar spectrum to visible light range [5]. The advantages of dye sensitizer includes low cost, minimal and simple fabrication process [6]. However, dye-sensitizer should have strong attachment to the surface of metal oxide semiconductor to achieved higher efficiency in PEC system [7]. Other than that, recombination also influenced the photocurrent generation in PEC reaction. Yet, the electron injection of dyes sensitizer is very fast while the back reaction is slow, hence the rate of recombination believed to be very small [8].

Synthetic dyes such as ruthenium complexes may offer high efficiency in PEC however, due to its expensive cost and rarity as well as toxic materials, substantially lead to the use natural dye as sensitizer [9]. Up till now, various natural dyes pigments from plants and fruits has been utilized such as anthocyanins, betalains, chlorophyll and carotenoids because of their low cost in extraction process while having good light absorption in visible region [1013]. Among all of the natural dye pigments, betalains is the most suitable candidate as a sensitizer to $\mathrm{TiO}_{2}$ photoelectrode as its having essential anchoring group that can attached efficiently onto $\mathrm{TiO}_{2}$ surface which is carboxyl group [14].

Red pitaya fruit is one of the new focuses for dye-sensitizers as it rich in betalains pigment. Betalain can be found in both peel and flesh of the fruit and also can be divided into the red-violet betacyanins and yellow-orange betaxanthins group that promise variants in colour. However, in this study focused more on pitaya peel as it is a leftover product especially in beverage industries. The deep purple colour observed in pitaya peel contributes by at least seven known betalain that have identical maximum light absorption $\left(\lambda_{\max }\right)$ namely betanin, isobetanin, betanidin, isobetanidin, phyllocactin, and bougainvilllein-r-I [15]. The advantage of betalains possess over other pigments is its anchor group that adsorb efficiently onto atoms of semiconductor. The study of betalain dye molecules bonding to the $\mathrm{TiO}_{2}$ subtrate has been reported previously. They suggested that ability of betalain's anchor group, carboxyl is the key factors to an efficient PEC reaction [16].

So far, the literature study work on pitaya peel dye in PEC water splitting is still barely known [17]. Thus, our research particular interest is the uses of natural pitaya peel dye molecules as light harvester sensitizer and also finding the influence of dye molecules added in liquid electrolyte.

\section{Dye pigment extraction}

\section{Materials and Methods}

Pitaya peel was macerated with double distilled water in a blender until completely homogenized in room temperature. The mixture is filtered by using vacuum filter to extract the dye and stored at $20{ }^{\circ} \mathrm{C}$ prior to analysis. Any contact of the dye extract to the light was inhibited to avoid change in colour.

\section{Fabrication of thin films}

Prior to fabrication process, Fluorine-doped Tin Oxide (FTO) glasses were cleaned using ultrasonicator by immersed into three different solvent sequentially; ethanol (Merck), acetone (Merck) and single distilled water for 5 minutes each at $30^{\circ} \mathrm{C}$. After that, the cleaned FTO glasses were dried at room temperature. In the meantime, $\mathrm{TiO}_{2}$ paste was prepared using nanoparticles powder of titanium dioxide P25 Degussa (Sigma Aldrich) mixed with double distilled water at ratio 1:3 of mass $(\mathrm{g})$ to volume $(\mathrm{ml})$. Then, the paste was stirred by using spatula to ensure 
homogenous mixture. The $\mathrm{TiO}_{2}$ paste was coated on top of FTO glass by Doctor Blade method and the thickness of thin films were controlled by taping the scotch tape at sides of FTO glass. Later, $\mathrm{TiO}_{2}$ thin film were calcined and sintered in a furnace at $450{ }^{\circ} \mathrm{C}$ for 2 hours with constant heating of $5{ }^{\circ} \mathrm{C} / \mathrm{min}$. The preparation is carried out in duplicates to prepare $\mathrm{TiO}_{2}$ with dye sensitizer thin films.

After cooling down, the sintered $\mathrm{TiO}_{2}$ thin film was soaked into a container filled with pitaya peel dye up to 24 hours in room temperature and dark condition to allow the adsorption of the dye molecules as a sensitizer. Later, the non-adsorbed materials on $\mathrm{TiO}_{2}$ with dye sensitizer thin film were removed by distilled water. The thin film stored at $0^{\circ} \mathrm{C}$ for further analysis and any contact with light is prevented to keep its colour stability.

\section{Characterization and Photoelectrochemical (PEC) test of thin films}

All of thin films prepared were characterizes using X-ray diffraction measurement, XRD (Bruker D8 Advance diffractometer) with $\mathrm{CuK} \alpha$ radiation in determining its structure and crystallinity. The percentage of the anatase and rutile crystalline phase was determined using following Equation 1 [18]:

$$
\text { Anatase }(\%)=\frac{1}{1+1.265\left(\frac{I_{\text {rutile }}}{I_{\text {anatse }}}\right)} \times 100 \%
$$

where $I_{\text {anatase }}$ and $I_{\text {rutile }}$ are the intensities at highest peak of anatase and rutile phase respectively for $\mathrm{TiO}_{2}$. Menawhile, the size of crystal can be measured by using Scherrer Equation 2 [19]:

$$
\mathrm{D}=\frac{\mathrm{K} \lambda}{\beta \operatorname{kos} \theta}
$$

where $\mathrm{K}$ is the crystal shape factor (0.9), $\lambda$ is the wavelength of $\mathrm{x}$-ray $(\mathrm{CuK \alpha} 1=0.15406 \mathrm{~nm}), \beta$ is full width at half the maximum intensity (rad) and $\theta$ is diffraction angle.

The morphology, grain sizes, and thickness of the thin films were studied with scanning electron microscope, SEM (Zeiss AM10). Meanwhile, the light absorption of thin films was measured by UV-Vis spectrophotometer (PerkinElmer Lambda 35). Light absorption of thin film can be calculated using following Equation 3:

$$
\mathrm{T}=\mathrm{e}^{-\alpha \mathrm{d}}
$$

where $\mathrm{T}$ is normalised transmittance, $\alpha$ is the absorption coefficient, $d$ is the thickness of the film $(\mathrm{cm})$. Besides that, the optical absorption coefficient is corresponding to the energy band gap $\left(E_{g}\right)$ determined by using the Tauc formula (Equation 4):

$$
\mathrm{Ah} v=\mathrm{B}\left(\mathrm{h} v-\mathrm{E}_{\mathrm{g}}\right)^{\mathrm{n}}
$$

where $\mathrm{A}$ is a absorption coefficient, $\mathrm{B}$ is a constant; $\mathrm{E}_{\mathrm{g}}$ is optical band gap energy of the film and $\mathrm{n}$ is the exponent. For crystalline semiconductors, $\mathrm{n}$ is $1 / 2,3 / 2,2$, and 3 when the transition is direct allowed, direct forbidden, indirect allowed and indirect forbidden respectively.

For the study of photoelectrochemical (PEC) activity, FTO glass coated with thin films were assembled with copper wire as described by Minggu et al [20] to form photoelectrodes. A PEC cell set-up with optical window was used with three electrodes system which consists of a working electrode (fabricated photoelectrodes), a counter electrode (platinum electrode) and a reference electrode (Saturated Calomel Electrode) whereas double distilled water with dye as electrolyte. Beforehand, the electrolyte was purged with nitrogen gas for 30 minutes. The analysis was carried out under $100 \mathrm{mWcm}^{-2}$ Xenon full arc lamp as light source with Ametek Versastat 4. The initial and final potential was set to $-0.5 \mathrm{~V}$ and $1.5 \mathrm{~V}$ respectively where the scan rate is $0.05 \mathrm{~V} / \mathrm{s}$. 


\section{Morphological analysis}

\section{Results and Discussion}

The images of surface and cross sectional morphology for bare $\mathrm{TiO}_{2}$ and $\mathrm{TiO}_{2}$ with dye sensitizer thin films can be observed using Scanning Electron Microscopy (SEM) as shown in Figure 1. The surface of $\mathrm{TiO}_{2}$ thin film demonstrates porous with good uniformity which can be benefit to support dye adsorption [21]. The thickness of bare $\mathrm{TiO}_{2}$ has been measured from cross-sectional image which is approximately $6 \mu \mathrm{m}$ meanwhile dye-sensitized $\mathrm{TiO}_{2}$ is approximately $8 \mu \mathrm{m}$ which is $2 \mu \mathrm{m}$ thicker than the bare $\mathrm{TiO}_{2}$. Dye particles were not clearly visible on the surface and cross-sectional of $\mathrm{TiO}_{2}$ with dye sensitized thin films due to very small size of dye molecule. Besides that, the particles size of $\mathrm{TiO}_{2}$ is almost in the same size and agglomerated with $40 \mathrm{~nm}$ in average.
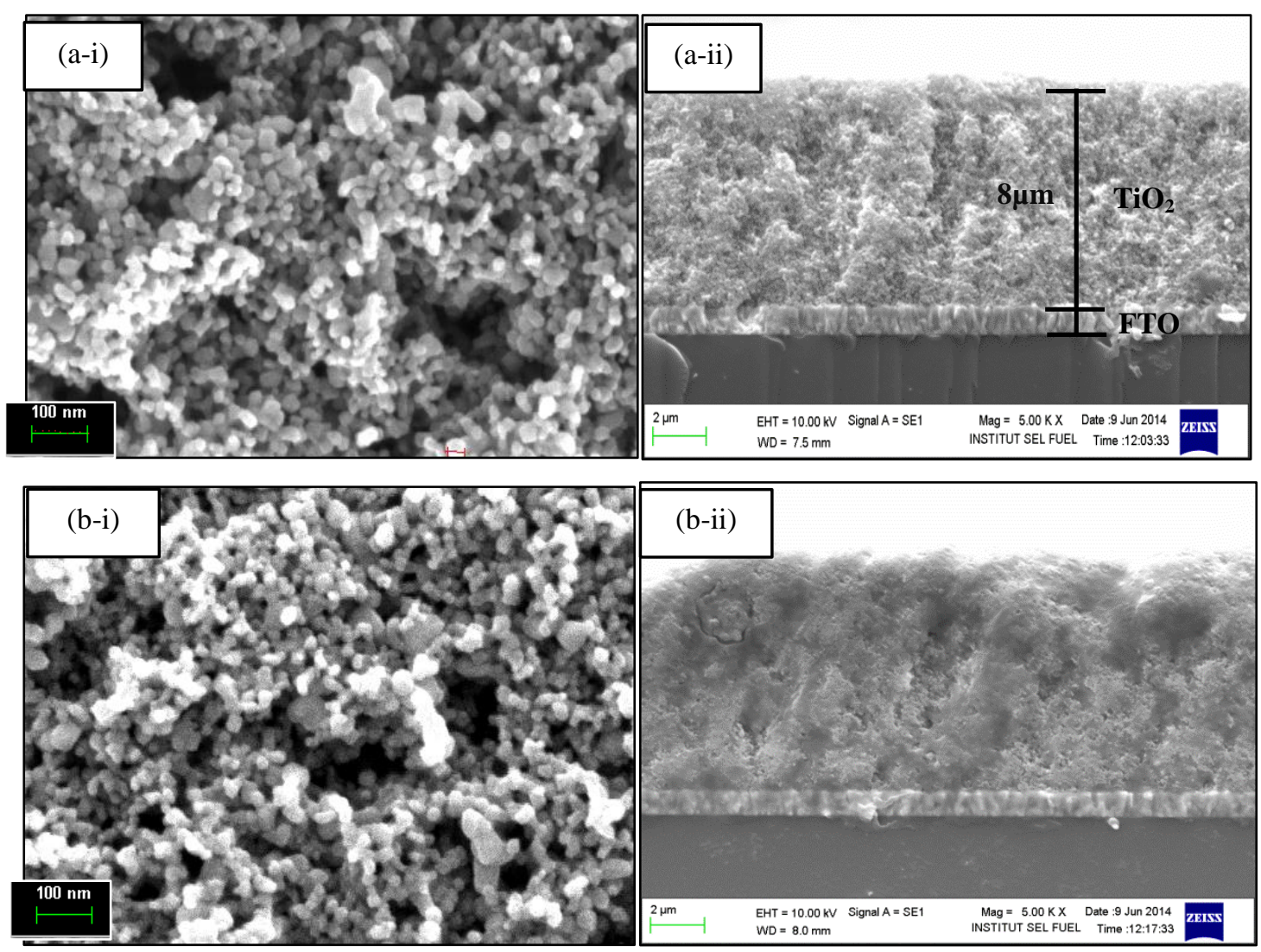

Figure 1. SEM images of (a) bare $\mathrm{TiO}_{2}$ and (b) dye-sensitized $\mathrm{TiO}_{2}$ thin films for its (i) surface and (ii) cross sectional respectively

\section{Crystalline structure of thin films}

Figure 2 shows the X-Ray Diffraction (XRD) pattern of $\mathrm{TiO}_{2}$ and dye-sensitized $\mathrm{TiO}_{2}$ thin films deposited onto FTO surface. The P25 Degussa $\mathrm{TiO}_{2}$ nanoparticles contain $74 \%$ anatase and $26 \%$ rutile with average crystallite size of $20 \mathrm{~nm}$ obtained from Equation (1) and (2), respectively. Anatase peaks were observed at $2 \theta$ of $25.43^{\circ}, 48.15^{\circ}$ and $54.70^{\circ}$ where correspondingly located at plane (101), (200) and (105) which in agreement with reported by Hamadanian et al. [21]. Meanwhile, the strongest peak of rutile appears at $27.55^{\circ}$ at plane (110). In general, anatase phase is phocatalytically more active compared to rutile due to low rate of eletron-hole recombination [22]. Besides, the addition of dye sensitizer on $\mathrm{TiO}_{2}$ thin films did not change the percentage of the anatase and rutile crystalline phase. However a new diffraction peak was exhibited at $2 \theta$ of $26.64^{\circ}$ due to the present of mineral salts in dye 
which later form crystal phase. In addition, there is increment in intensity of $\mathrm{TiO}_{2}$ peaks which suggest that the crystallinity of $\mathrm{TiO}_{2}$ is improved with adsorption of dye particles to $\mathrm{TiO}_{2}$ crystal lattice.

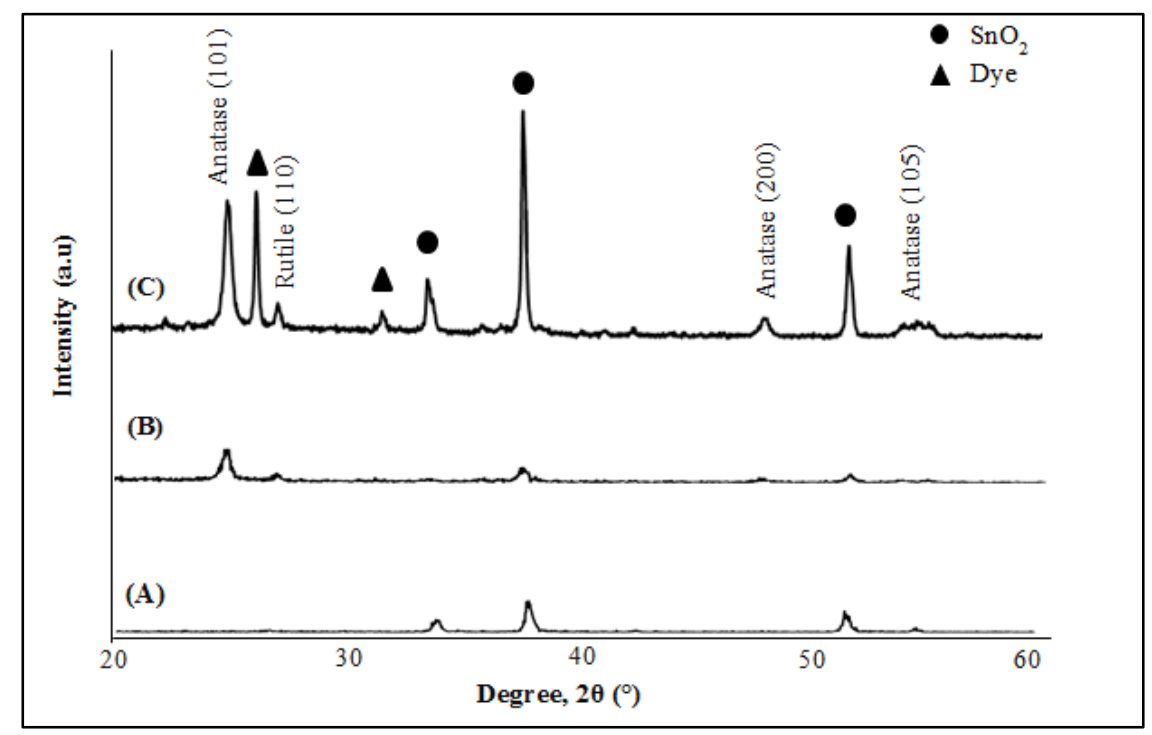

Figure 2. X-Ray Diffraction (XRD) pattern of (A) FTO, (B) $\mathrm{TiO}_{2}$ and (C) dye-sensitized $\mathrm{TiO}_{2}$ thin films deposited onto FTO

\section{Optical light absorption and band edge analysis}

Measurement of optical light absorption and band edge of pitaya peel dye and thin films has been done using UVVisible spectrophotometer. The visible light makes majority of solar spectrum at wavelength range between $400 \mathrm{~nm}$ and $800 \mathrm{~nm}$. Generally, the natural pitaya peel extracts contains mixture of several group pigments of betalain. In this study, the maximum light absorption $\left(\lambda_{\max }\right)$ for betalain pigments at about $546 \mathrm{~nm}$ as shown in Figure 3 which almost same as characteristic absorption of betacynanin, one of the red violet betalain group [23]. It shows that they have good light absorption at visible light portion and can utilize more photon energy. From the equation (3) and (4) shown in Section 2.3, the energy band gap, $\mathrm{E}_{\mathrm{g}}$ of pitaya peel dye is $2.1 \mathrm{eV}$ which include in the range of ideal band gap for $\mathrm{PEC}\left(1.23 \mathrm{eV}<\mathrm{E}_{\mathrm{g}}<3.0 \mathrm{eV}\right)$.

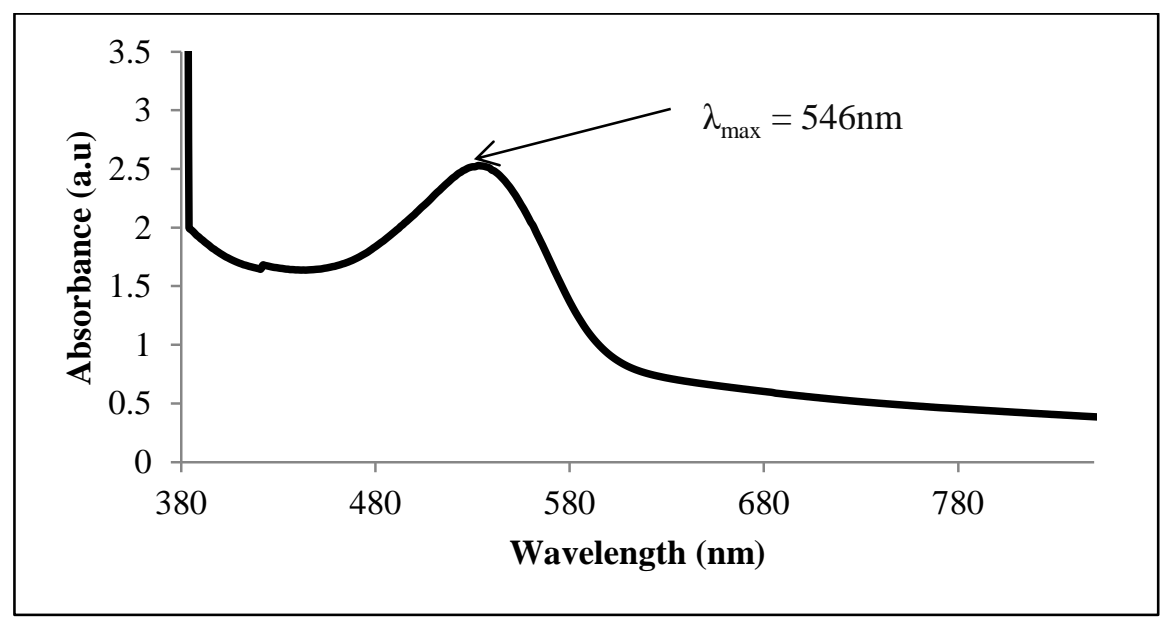

Figure 3. UV-Vis spectrum of pitaya peel dye pigment 
(A)

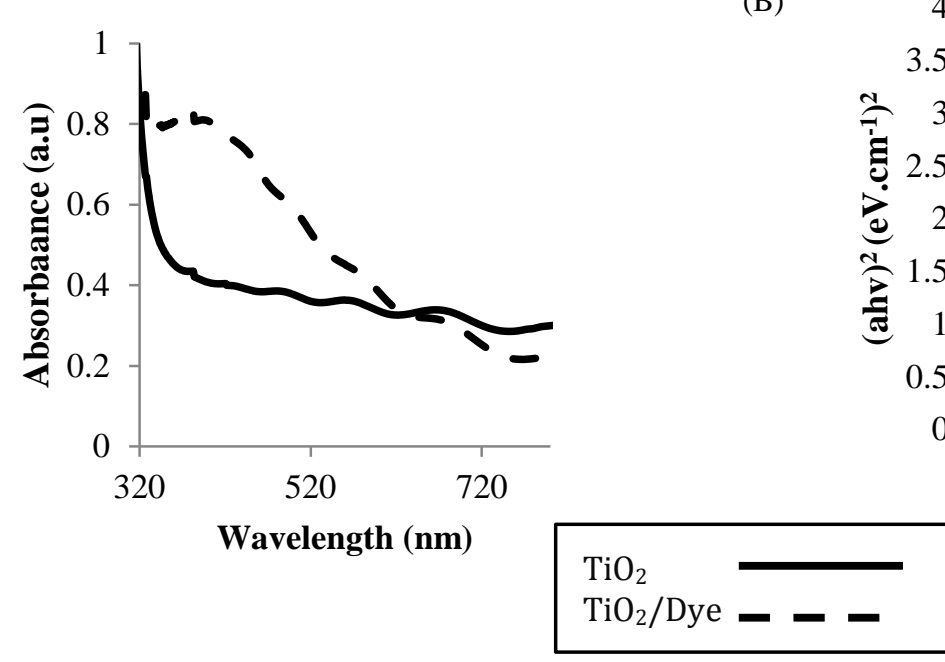

(B)

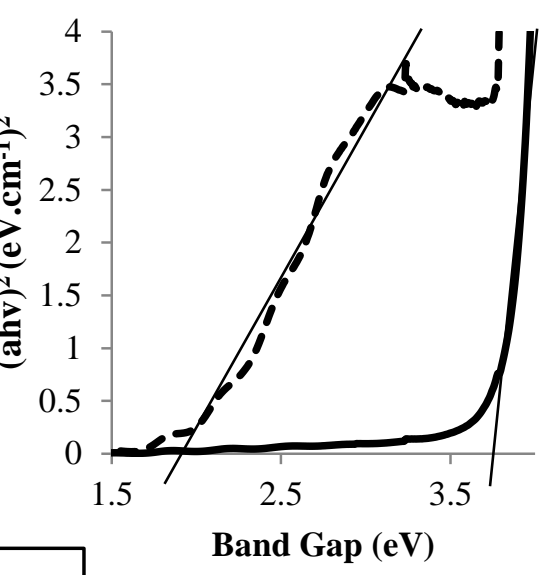

Band Gap (eV)

Figure 4. Optical light absorption (A) and direct allowed transition band gap (B) of bare $\mathrm{TiO}_{2}$ and dye-sensitized $\mathrm{TiO}_{2}$ thin films respectively

\section{Photoelectrochemical analysis}

Figure 5 shows measurement of photocurrent density for bare $\mathrm{TiO}_{2}$ and dye-sensitized $\mathrm{TiO}_{2}$ photoelectrodes in different concentration of dye in water electrolyte. The highest photocurrent density achieved by bare $\mathrm{TiO}_{2}$ are by $6.25 \%$ and $12.5 \% \mathrm{v} / \mathrm{v}$ concentration of pitaya peel dye in the electrolyte which is $93 \mu \mathrm{A} / \mathrm{cm}^{2}$ as shown in Figure 5 (A). However, the increased concentration of dye in electrolyte has decreased the photocurrent density with 66 $\mu \mathrm{A} / \mathrm{cm}^{2}$ at $100 \% \mathrm{v} / \mathrm{v}$ concentration of dye. In the meantime, the lowest photocurrent for bare $\mathrm{TiO}_{2}$ is $43 \mu \mathrm{A} / \mathrm{cm}^{2}$ without the addition of dye molecule electrolyte $(0 \% \mathrm{v} / \mathrm{v})$. From the Figure 5(B), dye-sensitized $\mathrm{TiO}_{2}$ shows the increment in photocurrent density compared to bare $\mathrm{TiO}_{2}$ where the highest photocurrent gained is $127 \mu \mathrm{A} / \mathrm{cm}^{2}$ in $6.25 \% \mathrm{v} / \mathrm{v}$ concentration of pitaya peel dye in the electrolyte. Meanwhile, zero adding of dye molecule $(0 \% \mathrm{v} / \mathrm{v})$ has produced the lowest photocurrent which is around $52 \mu \mathrm{A} / \mathrm{cm}^{2}$.

From the result, the present of dye-sensitizer layer on top of $\mathrm{TiO}_{2}$ film has enhanced the production of photocurrent. This is due to the betalain molecules in pitaya peel dye-sensitizer has improved the light absorption of $\mathrm{TiO}_{2}$ thus reducing the band gap. Besides that, functional group of carboxylic acid in betalains have forms a reversible binding with high equilibrium binding constant between $\mathrm{TiO}_{2}$ surface and dye molecules in order to establish bonds and attached efficiently [24]. In dye-sensitized $\mathrm{TiO}_{2}$ photoelectrode, the absorption of photon energy cause the electron transfer from highest occupied molecular orbital (HOMO) to lowest unoccupied molecular orbital (LUMO) following dihydropyridinie which attached on carboxyl group of dye-sensitizer. This caused photoexcitation dye state coupled electronically with an acceptor states in conduction band $\mathrm{TiO}_{2}$ and lead to fast electron injection and increased photocurrent generation $[10,16,25]$.

In the other hand, water is a poor electrolyte [26] and proven in this study as having the lowest photocurrent density for both bare $\mathrm{TiO}_{2}$ and $\mathrm{TiO}_{2}$ with dye sensitizer $(0 \% \mathrm{v} / \mathrm{v})$. However, the addition of dye molecules in electrolyte has shown increment in the photocurrent generation for both photoelectrodes. This may due to degradation of dye in electrolyte has made it as an electron donor to fill-up holes leaved by photoexcited electrons. Moreover, for dyesensitized $\mathrm{TiO}_{2}$ photoelectrode, dye-added molecules in the electrolyte has reduce driving force of desorption of the dye from $\mathrm{TiO}_{2}$ surface hence increase its stability in water [27]. 

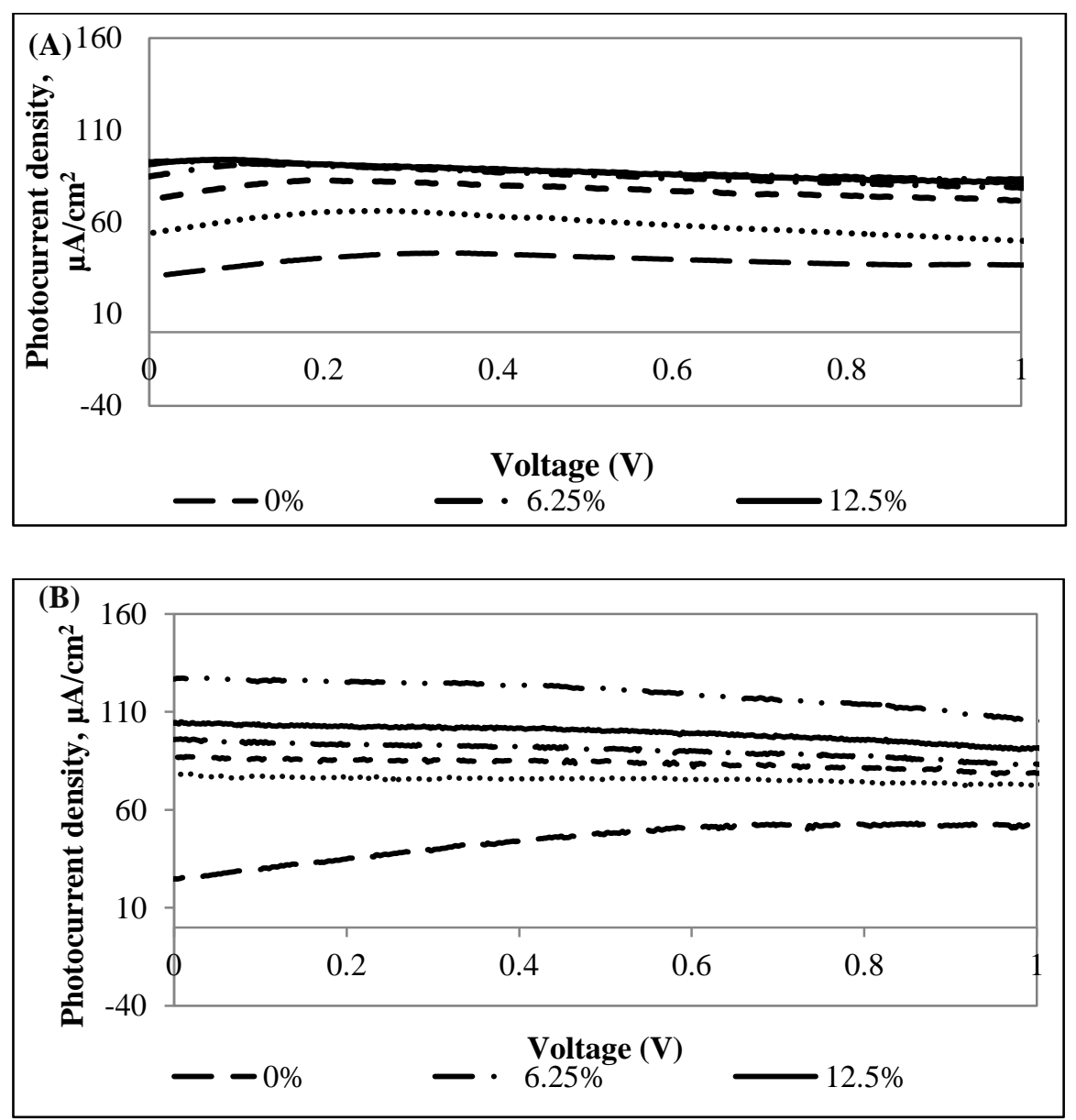

Figure 5. Performance of photocurrent density of (A) bare $\mathrm{TiO}_{2}$ and (B) $\mathrm{TiO}_{2}$ with dye sensitizer on different concentrations of pitaya peel dye in electrolyte

\section{Conclusion}

In this work, dye-sensitized $\mathrm{TiO}_{2}$ was successfully fabricated using pitaya peel dye. There is no significant change in morphological studies of dye-sensitized $\mathrm{TiO}_{2}$ thin film compare to bare $\mathrm{TiO}_{2}$ due to its very fine of dye particle size. However, the crystallinity of $\mathrm{TiO}_{2}$ has improved by the present of dye's crystal structure without change its phase. Besides, the light absorption dye-sensitized $\mathrm{TiO}_{2}$ also has extended into visible light region. By using pitaya peel as dye-sensitizer has shown an increment in photocurrent generation in water splitting reaction. Furthermore, additional of dye molecules also has influenced photocurrent density where dye-sensitized $\mathrm{TiO}_{2}$ photoelectrodes with $6.25 \% \mathrm{v} / \mathrm{v}$ of dye in electrolyte has the highest photocurrent density with $127 \mu \mathrm{A} / \mathrm{cm}^{2}$ under the Xenon lamp.

\section{Acknowledgement}

The authors would like to thank Universiti Kebangsaan Malaysia for providing the facilities and research grant (DIP-2012-27) and (GUP-2013-068).

\section{References}

1. Jeng, K.T., Liu, Y.C., Leu, Y.F., Zeng, Y.Z., Chung, J.C. and Wei, T.Y. (2010). Membrane electrode assemblybased photoelectrochemical cell for hydrogen generation. International Journal of Hydrogen Energy, 35(20): 10890 - 10897. 
2. Ng, K. H., Minggu, L. J., Jumali, M. H. and Kassim, M. (2012). Fotoelektrod tungsten trioksida terdop nikel untuk tindak balas pembelahan air fotoelektrokimia. Sains Malaysiana, 41(7): 893 - 899.

3. Manoharan, K. and Venkatachalam, P. (2015). Photoelectrochemical performance of dye sensitized solar cells based on aluminum-doped titanium dioxide structures. Materials Science in Semiconductor Processing, 30: $208-217$.

4. Al-Bat'hi, S. A. M., Alaei, I. and Sopyan, I. (2013). Natural photosensitizers for dye sensitized solar cells. International Journal of Renewable Energy Research, 3(1): 138 - 143.

5. Mark Lee, W. F., Minggu, L. J. and Kassim, M. (2012). Sifat foto-kimia kompleks molibdenum ditiolena. Sains Malaysiana, 41(5): $597-601$.

6. Zhang, J., Jarboui, A., Vlachopoulos, N., Jouini, M., Boschloo, G. and Hagfeldt, A. (2015). Photoelectrochemical polymerization of EDOT for solid state dye sensitized solar cells: role of dye and solvent. Electrochimica Acta, 179: 220 - 227.

7. Calogero, G., Yum, J.-H., Sinopoli, A., Di Marco, G., Gratzel, M. and Nazeeruddin, M. K. (2012). Anthocyanins and betalains as light-harvesting pigments for dye-sensitized solar cells. Solar Energy, 86: 1563 -1575 .

8. Tennakone, K., Jayaweera, P. V. V. and Bandaranayake, P. K. M. (2003). Dye-sensitized photoelectrochemical and solid-state solar cells: charge separation, transport and recombination mechanisms. Journal of Photochemistry and Photobiology A: Chemistry, 158: 125 - 130.

9. Torchani, A., Saadaoui, S., Gharbi, R. and Fathallah, M. (2015). Sensitized solar cells based on natural dyes. Current Applied Physics, 15: 307 - 312.

10. Calogero, G., Di Marco, G., Caramori, S., Cazzanti, S., Argazzic, R. and Bignozzi, C.A. (2009). Natural dye senstizers for photoelectrochemical cells. Energy \& Environmental Science, 2: 1162 -1172.

11. Khan, M. A., Khan, S. M. M., Mohammed, M. A., Sultana, S., Islam, J. M. M. and Uddin, J. (2012). Sensitization of nanocrystalline titanium dioxide solar cells using natural dyes: Influence of acids medium on coating formulation. American Academic \& Scholarly Research Journal, 4 (5): 1 - $10 .$.

12. Shanmugam, V., Manoharan, S., Anandan, S. and Murugan, R. (2013). Performance of dye-sensitized solar cells fabricated with extracts from fruits of ivy gourd and flowers of red frangipani as sensitizers. Spectrochimica Acta Part A: Molecular and Biomolecular Spectroscopy, 104: 35 - 40.

13. Liao, C. H., Huang, C. W. and Wu, J. C. S. (2012). Hydrogen production from semiconductor-based photocatalysis via water splitting. Catalysts, 2: 490 - 516.

14. Zhang, D., Lanier, S. M., Downing, J. A., Avent, J. L., Lum, J. and McHale, J. L. (2008). Betalain pigments for dye-sensitized solar cells. Journal of Photochemistry and Photobiology A: Chemistry, 195: 72 - 80.

15. Rebecca, O. P. S., Zuliana, R., Boyce, A. N. and Chandran, S. (2008). Determining pigment extraction effieciency and pigment stability of dragon fruit (Hylocereus polyrhizus). Journal of Biological Sciences, 8(7): $1174-1180$.

16. Oprea, C. I., Dumbrava, A., Enache, I., Georgescu, A. and Gîrtu, M. A. (2012). A combined experimental and theoretical study of natural betalain pigments used in dye-sensitized solar cells. Journal of Photochemistry and Photobiology A: Chemistry, 240: 5 - 13.

17. Jamilah, B., Shu, C. E., Kharidah, M., Dzulkifly, M. A. and Noranizan, A. (2011). Physico-chemical characteristics of red pitaya (Hylocereus polyrhizus) peel. International Food Research Journal, 18: 279 - 286.

18. Spurr, R.A. and Myers, H. (1957). Quantitative analysis of anatase-rutile mixtures with an X-Ray diffractometer. Analytical Chemistry, 29(5): 760 - 762.

19. Scherrer, P. (1918). Bestimmung der Grösse und der inneren Struktur von Kolloidteilchen mittels Röntgenstrahlen. Nachr. Ges. Wiss. Göttingen, 26: 98 - 100.

20. Minggu, L. J., Daud, W. R. W. and Kassim, M. (2010). An overview of photocells and photoreactors for photoelectrochemical water splitting. International Journal of Hydrogen Energy, 35: 5233 - 5244.

21. Hamadanian, M., Safaei-Ghomi, J., Hosseinpour, M., Masoomi, R. and Jabbari, V. (2014). Uses of new natural dye photosensitizers in fabrication of high potential dye-sensitizedsolarcells (DSSCs). Materials Science in Semiconductor Processing, 27: 733 - 739.

22. Kusmierek, E. and Chrzescijanska, E. (2015). Application of TiO2-RuO2/Ti electrodes modified with WO3 in electro- and photoelectrochemical oxidation of Acid Orange 7 dye. Journal of Photochemistry and Photobiology A: Chemistry, 302: 59- 68. 
23. Woo, K. K., Ngou, F. H., Ngo, L. S., Soong, W. K. and Tang, P. Y. (2011). Stability of betalain pigment from red dragon fruit (Hylocereus polyrhizus). American Journal of Food Technology, 6(2): 140 - 148.

24. Hug, H., Bader, M., Mair, P. and Glatzel, T. (2014). Biophotovoltaics: Natural pigments in dye-sensitized solar cells. Applied Energy, 115: 216 - 225.

25. Mark Lee, W. F., Ng, K. H., Minggu, L. J., Umar, A. A. and Kassim, M. (2012). Penentuan aras jalur tenaga kompleks tungsten nitrosilditiolena. Sains Malaysiana, 41(4): 439 - 444.

26. Grimes, C. A., Varghese, O. K. and Ranjan, S. Light, Water, Hydrogen: The Solar Generation of Hydrogen by Water Photoelectrolysis. 2008: Springer Science+Business Media.

27. Heo, N., Jun, Y. and Park, J. H. (2013). Dye molecules in electrolytes: new approach for suppression of dyedesorption in dye-sensitized solar cells. Scientific Reports, 3: 1712. 